\title{
FRANCOUZSKÁ BÍLÁ KNIHA OBRANY A BEZPEČNOSTI
}

\section{FRENCH WHITE PAPER ON DEFENCE AND SECURITY}

\author{
Vlastimil GALATÍK $K^{*}$
}

\begin{abstract}
Abstrakt
Text stručně seznamuje s francouzskou Bílou knihou obrany a bezpečnosti, která navazuje na obdobný materiál z roku 1994. Současně jsou uváděny některé závěry a shrnutí autora kobsahu některých statí i k celkovému významu dokumentu. Bílá kniha stanovuje zásady obrany a bezpečnosti zemé na období př́ítích 15 let. Materiál je charakterizován zásadně novým pohledem a přístupem k otázkám obrany a bezpečnosti: komplexní pojetí a společné úsilí všech predpokládaných aktérü. Kostru Bílé knihy tvoři 16 klíčových bodu. Zdưrazněna je role občana, který se stává ústředním prvkem strategie obrany. Dochází také k prehodnocení strategických funkcí a jejich pravidelné aktualizaci. K naplnění strategie obrany je předpokládaná $i$ reforma ozbrojených sil a ř́dící struktury bezpečnosti a obrany.
\end{abstract}

\begin{abstract}
This paper informs of the French White Paper on defence and national security that resumes similar document developed in 1994. In addition, it includes author's comments and conclusions to/from certain parts as well as the entire document. White Paper stipulates the principles of national defence and security for the period of next 15 years. The characteristic of this is a completely new point of view of and attitude towards defence and security issues: comprehensive approach and joint effort of all expected players. White Paper's frame consists of 16 key points. It accentuates citizen's role as it becomes the central element of defence strategy. Also, strategic functions are reviewed and regularly updated. It contains armed forces branches' expected strength and primary missions. Meeting defence strategy goals supposes also armed forces reform as well as the reform in security and defence control structures.
\end{abstract}

\section{Klíčová slova}

Francouzská bílá kniha, národní bezpečnost, obrana, strategické funkce, ambice.

\section{Keywords}

French White Paper, national security, defence, strategic functions, ambitions.

$$
* * *
$$

\section{ÚvoD}

Dne 17. června tohoto roku prezident Francouzské republiky a vrchní velitel ozbrojených sil Nicolas Sarkozy představil před 3500 vojáky, policisty i civilisty ministerstva vnitra a obrany novou strategii obrany a bezpečnosti Francie pro následujících patnáct let. Tato politika je detailně rozpracována $\mathrm{v}$ Bílé knize obrany a národní bezpečnosti, která byla zveřejněna v tentýž den. Nová Bílá kniha navazuje na knihy z let 1972 a 1994. Předešlé Bílé knihy se zabývaly pouze otázkami obrany, kdežto aktuální Bílá kniha pokrývá současně jak problematiku obrany, tak i bezpečnosti.

Nová Bílá kniha byla dlouho očekávána zejména odbornou veřejností a na jejím zpracování se podílely velmi rozsáhlé týmy za řízení komise pro Bílou knihu a byly zohledňovány názory širokého spektra odborníků na vojenskou a bezpečnostní problematiku, politiků i představitelů civilních sdružení, a to nejen francouzských. Názory na obranu a národní bezpečnost jsou

\footnotetext{
*E-mail: Vlastimil.Galatik@unob.cz.
} 
vyjádřeny na více než 400 stranách části nazvané „Diskuse“ („Les Débats“), která je jednou z částí Bílé knihy.

Samotná Bílá kniha je poměrně rozsáhlá a na 350 stranách je členěna do čtyř částí a osmnácti kapitol. Mimo předmluvu prezidenta republiky, úvod a závěr jsou jednotlivé části vzájemně provázány a rozvíjí úvahy od globálních bezpečnostních problémů přes francouzské mezinárodní ambice až ke zvolené strategii a k reformě systému bezpečnosti a obrany země. Názvy jednotlivých částí dostatečně ilustrují jejich obsah:

1. Od globalizace ke strategii národní bezpečnosti (strategická nejistota; di̊sledky pro Francii a Evropu; strategie národní bezpečnosti).

2. Evropské a mezinárodní ambice Francie (evropské ambice; transatlantická renovace; kolektivní bezpečnost $v 21$. století).

3. Nová akční strategie (jaká zasazení?; znát a predem zasahovat; predcházet; odstrašovat; chránit; zasahovat; ozbrojené síly).

4. Dynamika reformy (profesionálové ve službě národa; reorganizace veřejné moci; prưmysl a výzkum; finanční úsilí; sepětí národa).

Vzhledem ke značnému rozsahu knihy je možné pouze vybrat určité závěry nebo zevšeobecnění, která mohou dokumentovat jak význam tohoto dokumentu pro bezpečnost a obranu Francie v prř́štích patnácti letech, tak i složitost problémů, se kterými se zpracovatelé museli vypořádat prri jeho tvorbě.

\section{KLÍČOVÉ BODY BÍLÉ KNIHY}

V doprovodných materiálech je samostatně prezentováno 16 klíčových bodů Bílé knihy, které jsou podrobněji rozebrány $\mathrm{v}$ jednotlivých kapitolách dokumentu v plném znění:

1. Pochopit světové změny, obzvláště pod vlivem globalizace. Svět není nezbytně více nebezpečným, ale stává se více nestabilním a nepředvídatelným.

2. Brát $\mathrm{v}$ úvahu společně možná rizika a hrozby ve strategii národní bezpečnosti, která definuje nejen politiku obrany, ale také politiky vnitřní a civilní bezpečnosti, diplomacii a ekonomickou politiku.

3. Spojit strategii národní bezpečnosti kolem pěti strategických funkcí: znát a předem zasahovat; předcházet; odstrašovat; chránit; zasahovat a tyto funkce aktualizovat každé 4 roky.

4. Redukovat nejistotu, která charakterizuje globalizaci cestou znalostí a preventivním zasahováním k udržení autonomie a strategické iniciativy politiků a vojáků s rozhodovací pravomocí.

5. Umístit ochranu obyvatelstva a teritoria do jádra strategie, aby čelila novým možnostem zranitelnosti a krizím velkého rozsahu.

6. Sladit schopnosti prevence a zasazení na ose Středozemní moře / Arabsko-perský záliv / Indický oceán - zóny s nejvyšším rizikem - při zachování kapacit na západě Afriky, v sahelském pásmu a v oblasti Antily - Guayana.

7. Udržet jaderné odstrašování jako hlavní základ národní strategie. Poslední záruka bezpečnosti a nezávislosti Francie, kterou má pro jedinou funkci, což je zabránění agresi státního původu proti životním zájmům země na jakémkoli místě a v libovolné formě. 
8. Posílit schopnosti vojenských akcí Evropské unie, významného aktéra mezinárodní bezpečnosti a ochrany evropských občanů.

9. Podtrhnout vzájemné doplňování Evropské unie a NATO, 21 z 26 zemí, členů Aliance, přináleží k EU.

10. Modernizovat nástroje a připravit budoucnost pro koherentní obranu: prioritní posílení ochrany sil v operacích cestou zahájení nových programů (zpravodajství, informační boj).

11. Dosáhnout operačních cílů vlády novým formátem ozbrojených sil a jejich schopností vyslání (pozemní, vzdušné síly, námořnictvo):

a. zahraniční operace: vyslání 30000 mužů z pozemních operačních sil čítajících 88000 mužů;

b. národní teritorium: 5000 mužů ve stálé pohotovosti a 10000 mužů schopných mobilizace $\mathrm{v}$ př́ípadě závažné krize;

c. vzdušně-námořní skupina se svojí kompletní vzdušnou skupinou;

d. 300 bojových letounů dovolující vyslání 70 bojových letounů a desítku letounů v pohotovosti;

12. Udržet finanční úsilí Francie pro potřeby obrany: udržet roční zdroje (mimo penzijní náklady) v závazné výši, pak od roku 2012 zvyšovat tuto podporu závazně o 1 \% (rozpočtu obrany) ročně.

13. Poevropštit obranný průmysl. Je to evropský rámec, který musí přináležet projektům bojových letounů, bezpilotních průzkumných prostředků, křižujících střel, satelitům, elektronickým složkám atd. Tato akviziční politika musí zahrnovat také dimenzi nákupů na světovém trhu.

14. Reorganizovat veřejnou moc pro funkci strategie národní bezpečnosti. $K$ tomuto účelu založit Radu obrany a národní bezpečnosti, posílit roli Parlamentu a reformovat nařízení z roku 1959 stanovující všeobecnou organizaci obrany.

15. Dát civilnímu personálu nebo vojákům a ve všech oblastech nejvyšší stupeň profesionalismu. Spojit vzájemně přípravu, rozvíjet synergii mezi rekrutační politikou různých ministerstev. Bude založeno zvláštní odvětví pro oblast zpravodajství. Aktivizace v otázkách národní bezpečnosti bude zesílena u všech kategorií veřejných funkcí.

16. Zkoumat sepětí národa cestou přípravy a informování: obnovit den povolání pro přípravu k obraně, založit povinnou občanskou službu, založit nadaci strategické spolupráce, která podpoří Evropskou doktorandskou školu.

\section{KONCEPCE SPOLEČNÉHO ÚSILÍ}

Aktuální strategický kontext a nové hrozby, se kterými může být Francie konfrontována, zvláště hrozba terorismu, vyvolává uvědomění si její zranitelnosti ve vztahu k rizikủm úmyslně nebo neúmyslně vyvolaným.

Bílá kniha klade do popředí koncepci společného úsilí. Společné úsilí se definuje jako vůle státu a schopnost zemé, společnosti a veřejné moci odolávat důsledkům závažných událostí, následně rychle znovu nastolit normální fungování, a to za podmínek sociálně prijatelných.

Společné úsilí národa bude silnější, bude-li více spojeno s cíli obrany a bezpečnosti, což více zajistí národní bezpečnost. Společné úsilí vyžaduje nastolení dobré úrovně informovanosti občanů. 
Společné úsilí není ekvivalentem výrazu „sekuritizace fungování státu“, chápané jako snížení jeho zranitelnosti, zvýšení jeho schopnosti obnovit své fungování a morální podporu obyvatelstva. Společné úsilí má rozměr sociální, který zahrnuje nejen stát a všeobecněji veřejnou moc, ale také aktéry civilní společnosti. Jednodušeji, sekuritizace fungování státu je nezbytnou složkou společného úsilí, ale toto není součástí sekuritizace. Společné úsilí je současně cíl (pro státní administrativu) a stát samotný (pro společnost v nejširším slova smyslu).

Přes všechna opatření francouzská ekonomická infrastruktura zůstává vůči závažným rizikům velké šǐre mimořádně zranitelná. Co se týká státní a vládní infrastruktury, navzdory vzrůstu přípravy na závažné katastrofické události je situace pravděpodobně ještě relativně dobrá.

\section{STRATEGIE SOUSTŘEDĚNÁ NA OBČANA}

Charakteristickým rysem nové strategie národní bezpečnosti je její soustředění na občana. Tato dimenze je obzvláště vyjádřena v následujících úvahách a předpokládaných opatřeních:

1. Zvažování hrozeb a zranitelností, které mohou zasáhnout národní teritorium nebo populaci: terorismus, přírodní nebo technologické katastrofy, hrozby útoků balistickými střelami, informační útok.

2. Předběžná opatření a schopnost reakce čelící strategickému ,překvapení“, které by mohlo narušit každodenní život Francie.

3. Opatření ochrany obyvatelstva a teritoria, která přinášejí novou dimenzi zavedením specifických prostředků:

- Vzdušné, námořní střežení a střežení prostoru mimo atmosféru;

- ochrana proti hrozbě jaderné, radioaktivní, biologické a chemické;

- ochrana informačních systémů;

- $\quad$ koordinace ozbrojených sil se silami vnitřní a civilní bezpečnosti a operačních cílů určených armádě a civilním silám.

4. Vůle přímo angažovat členy parlamentu a zvolené lokální predstavitele v rozhodovacím procesu významném pro obranu a národní bezpečnost.

5. Výchova mládeže, zvolených představitelů a záložníků, aby bylo zlepšeno vnímání záležitostí dotýkajících se národní bezpečnosti uvnitř populace a podpořena dobrovolnost.

6. Zvažování společných vlastních opatření ke zvýšení společného úsilí: zavedení moderních prostředků výstrahy obyvatelstva; definování politiky komunikace před, během a po ukončení krize; politika prevence rizik a rozvoj cvičení, zahrnujících obyvatelstvo a jeho představitele.

\section{VELKÉ STRATEGICKÉ FUNKCE}

Strategie národní bezpečnost ve věku globalizace bude spočívat v nové rovnováze mezi pěti velkými strategickými funkcemi:

\section{Znalost a předvídání}

Vzhledem k nejistotám zvažovaným v příštích patnácti letech je tato funkce v popředí všech ostatních. Občané fakticky očekávají stát, který by byl schopný pochopit mezinárodní vývoj, připravovat a orientovat prostředky obrany a vnitřní bezpečnosti, aby napomohl francouzské 
společnosti se situaci přizpůsobit. Posílení francouzských schopností znát a předvídat tedy utvář́ životní nutnost pro období patnácti nejbližších let i let následujících.

\section{Prevence vzniku konfliktů nebo krizí}

Jedním z nejlepších způsobů garantujících bezpečnost Francie je co nejvčasnější reakce na případné konflikty. Francouzská preventivní strategie bude založena na prostředcích diplomatických, finančních, vojenských, právních a kulturních. Evropská unie a OSN hrají v tomto procesu ústřední roli.

\section{Jaderné odstrašování}

Zůstane poslední zárukou bezpečnosti Francie vůči každému státnímu protivníkovi, který by chtěl zaútočit na její životní zájmy jakýmikoli prostředky. Proti různorodosti současných situací, se kterými může být francouzské odstrašování konfrontováno, bude jeho důvěryhodnost založena na možnosti prezidenta republiky disponovat zcela nezávislým komplexem uzpůsobených prostředků.

\section{Ochrana}

Od 90. let, spojených s objevením se nových možností zranitelnosti, je ochrana obyvatelstva a teritoria v centru strategie národní bezpečnosti. Nejzávažnější výzvy, se kterými může být konfrontována veřejná moc, vyzývají k nové organizaci, k novým zařízením a k novým prostř̌edkům. Stát se bude organizovat, aby garantoval nejlepší možnou koordinaci mezi zařízeními vnitřní a civilní bezpečnosti na jedné straně, která čelí v první řadě těmto rizikům, a ozbrojenými silami na straně druhé, jejichž schopnosti musí být využity v př́íhodný okamžik, aby podpořily tato zařízení, a to podle rámce použití definovaného politickými představiteli.

\section{Intervence}

Intervence zůstane důležitým zpo̊sobem činnosti francouzských ozbrojených sil, obzvláště mimo národní území. Schopnost intervence musí umožnit zajištění strategických zájmů země a převzetí odpovědnosti za zajištění mezinárodní bezpečnosti. Nejčastěji se intervence bude odehrávat v mezinárodním rámci. Jen tři hypotézy připouštěji možné intervence čistě národní:

- ochrana francouzských občanů v zahraničí;

- realizace dvoustranných obranných dohod, které spojují Francii s řadou zemí;

- národní odpověd', která by mohla vyvolat rychlou odvetu za akce vedené proti francouzským zájmům.

Ve všech ostatních př́padech se intervenční strategie Francie odehraje vrámci mnohonárodním, což znamená $\mathrm{v}$ rámci OSN, Evropské unie, NATO nebo jiného vhodného uskupení a s využitím legitimity dané mezinárodním právem.

Jen kombinace těchto různých strategických funkcí umožní zajistit národní bezpečnost. Jejich úprava bude založena na pružnosti a možnostech dalšího vývoje. To bude tvořit cíl nových rozborů u prŕíležitosti každé aktualizace Bílé knihy, což se předpokládá každé čtyři roky.

\section{OZBROJENÉ SÍLY}

Nová strategie obrany a národní bezpečnosti vyvolává zákonitě potřebu hlubší reformy ozbrojených sil jako reakci na tendence vývoje bezpečnostního prostředí. Nižší riziko vzniku globálního konfliktu umožňuje snížení celkové velikosti ozbrojených sil. Současně se ukazuje i nižší potřeba velkých prvků, operačních svazů a svazků. 
Počty osob a techniky jednotlivých složek ozbrojených sil jsou stanoveny na základě předpokládaných rozhodujících úkolů k naplnění vojensko-politických ambicí Francie.

\section{Pozemní složka}

Pozemní síly musí umožnit současně:

- podílet se na ochraně národního teritoria posílením složky vnitřní bezpečnosti a civilní bezpečnosti, s prostředky umožňujícími zasadit až 10000 mužů na několik dní;

- $\quad$ působit v rámci významného mnohonárodního zasazení, v prostoru vzdáleném až 7-8 tisíc km, s rozvinutím až 30000 mužů během 6 měsíců, pro dobu trvání jeden rok, bez obnovy;

- udržet stálou schopnost akce a nezávislé reakce umožňující zasazení 5000 mužů po omezenou dobu;

- udržet síly prevence, mimo národní teritorium, soustředěné v bodech podpory př́edevším afrických zemích a v Arabsko-perském zálivu;

- zajistit přítomnost $\mathrm{v}$ zámořských územích z titulu sil suverenity, s prostředky bojiště, soustředěné na Guayaně, Réunionu a Nové Kaledonii a se schopností regionální reakce na krize.

Struktura pozemních sil sdruží:

- $\quad$ síly „rozhodujíci““, uzpůsobené pro boje s použitím nejvyššího násilí;

- síly „mnohoúčelové“, více orientované na prvotní vstup do operačního prostoru s překvapením, na fáze přechodné a na stabilizační operace;

- $\quad$ síly „pohotovostní“, s vysokou strategickou mobilitou.

Pozemní síly tvoří operační sílu v hodnotě 88000 mužů, organizovanou následně:

- 8 brigád vševojskových (lépe „všech zbraní“ - ,interarm“), které mají k dispozici 250 těžkých bojových tanků typu Leclerc, okolo 650 obrněných bojových vozidel typu VBCI (BVP), 80 bojových vrtulníků, 130 vrtulníků přepravních a disponujících 25000 individuálními bojovými komplety typu Félin;

- 3 specializované brigády;

- odpovídající prostředky podpory.

\section{Námořní složka}

Námořní síly musí umožnit:

- zajistit př́tomnost na moři strategickými oceánskými silami, zaručujícími především schopnost odvetného odstrašujícího úderu;

- střežit a kontrolovat přístupy k národnímu teritoriu jak v metropoli, tak i v zámoří;

- vést akce státu na moři v prostoru pod národní jurisdikcí (teritoriální vody, exkluzivní ekonomické zóny);

- přispívat k prevenci účastí na ovládnutí a kontrole vzdušně-námořního prostoru v zájmových zónách (západní Afrika, Arabsko-perský záliv a obzvláště Indický oceán), na 
zajištění bezpečnosti komunikačních tras, na kontrole plavby v rámci boje proti terorismu, proti nezákonnému pašování a proti ilegální imigraci;

- $\quad$ podílet se na intervenčních operacích a vojenské přitomnosti ve světě.

Souběžně musí mít schopnost nezávislé reakce, vycházející ze sil pohotovosti, která musí umožnit rozvinutí v bodově přesných operacích, jako jsou evakuace občanů v zahraničí, námořní protiteroristické akce nebo humanitární operace.

K vyplnění všech těchto poslání bude námořní složka vybavena především takto:

- 4 jaderné ponorky - nosiče střel (SNLE);

- 6 jaderných útočných ponorek (SNA);

- 1 letadlová lod' se svou vzdušnou skupinou;

- 18 fregat prvního řádu;

- 4 lodě pro vyslání sil a velení.

\section{Vzdušná složka}

Vzdušné síly musí umožnit:

- zajistit uskutečnění vzdušně-přepravního prvku odstrašení;

- $\quad$ uskutečňovat nepretržitým způsobem střežení a kontrolu vzdušných přistupů k národnímu teritoriu (metropole a zámořská území, obzvláště Guayana); složka bude schopna zesílit stálé prvky bezpečnosti až na 6 operačních patrol a 4 operační patroly specializované na boj proti pomalým letounům, jako i o prvky ochrany v prŕípadě mimořádných událostí (dvě nebo tři ,bubliny“ protivzdušné obrany);

- přispívat do zpravodajských informací nezbytných pro operace, pro střežení teritoria, získané $\mathrm{z}$ přístupů $\mathrm{k}$ teritoriu a z prostředí vzdušně-kosmického;

- vyslat do prostoru vzdáleného 7-8 tisíc $\mathrm{km}$ bojové vzdušné síly v počtu 70 bojových letounů, včetně letounů námořního letectva, $\mathrm{k}$ čemuž se dále přidávají přidružené letouny operační podpory.

Souběžně musí mít schopnost nezávislé reakce, vycházející ze sil pohotovosti, která musí umožnit rozvinutí v bodově přesných operacích, jako jsou evakuace občanů v zahraničí, námořní protiteroristické akce nebo humanitární operace.

Celková dimenze vzdušných sil jim umožní také:

- převzít velení vzdušného prvku vševojskových sil;

- vyslat do pěti dnů pohotovostní sled sil (1 500 vybavených mužů) na 7-8 tisíc km s dostatečnou autonomií.

K vyplnění všech těchto poslání budou mít vzdušné síly k dispozici:

- 300 moderních bojových letounů (Rafale, modernizované Mirage 2000-D), uskupené do jediného celku, jehož řízení bude uskutečňováno vzdušnými silami;

- 4 pokročilé systémy detekce a kontroly typu Awacs;

- prvek k doplňování paliva a transportní, zahrnující 14 strojů pro doplňování a kolem 70 transportních. 
V roce 2014 budou mít ozbrojené síly celkově 225000 osob, vojáků i civilistů:

- pozemní síly budou mít 131000 mužů;

- námořnictvo 44000 mužů;

- $\quad$ vzdušné síly 50000 mužů.

Celkově dojde ke snížení počtů v těchto třech složkách ozbrojených sil oproti současnému stavu zhruba o 37000 osob. U pozemních sil o 13 000, námořnictva o 11000 a vzdušných sil o 13000 osob.

\section{NOVÉ ŘíDÍCÍ STRUKTURY NÁRODNÍ BEZPEČNOSTI}

Nová strategie obrany a bezpečnosti Francie má významné dopady na oblast veřejné moci. Mění se celý systém rrízení ve vztahu k národní bezpečnosti, která je chápána mnohem komplexněji. Otázky spojené s obranou a bezpečností nejsou již pouze záležitostí resortů obrany či vnitra, ale budou se dotýkat i dalších ministerstev, orgánů místní správy a samosprávy, výzkumných institucí i samotných občanů. Avizované změny jsou nejvýznamnější za posledních takřka 50 let, to je od roku 1959, kdy vstoupilo v platnost nařízení stanovující všeobecnou organizaci obrany.

Na nejvyšší úrovni se předpokládá zavedení nové struktury orgánů řídících a realizujících otázky obrany a bezpečnosti.

\section{Politické řízení (vrcholová úroveň):}

Rada obrany a národní bezpečnosti řízená prezidentem republiky; Národní zpravodajská rada; Konzultační rada pro obranu a národní bezpečnost.

\section{Rada obrany a národní bezpečnosti}

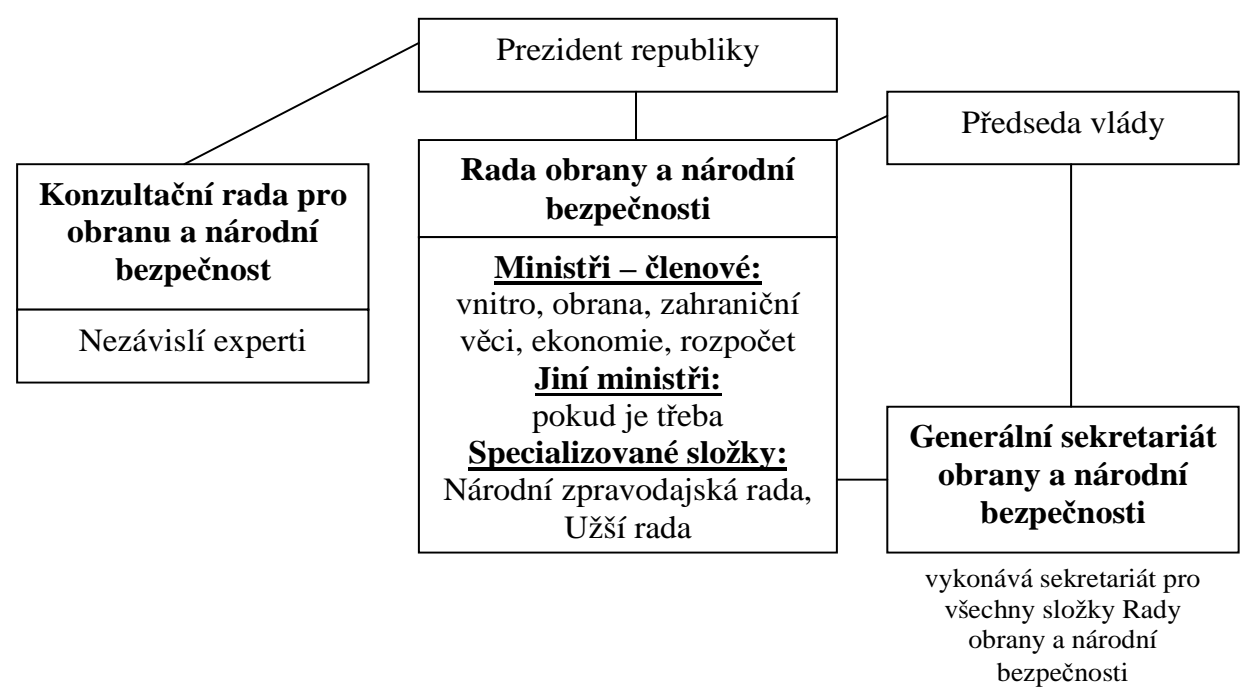




\section{Koordinace na úrovni předsedy vlády}

Generální sekretariát obrany a národní bezpečnosti; Agentura pro bezpečnost informačních systémů; Meziministerský výbor koordinace boje s hrozbami nukleárními, radiologickými, biologickými a chemickými; Meziministerská komise podpory velkých kontraktů; Středisko „obrany a zahraničních věcí“ a středisko „vnitřní bezpečnosti“ pro zkoumání otázek bezpečnosti.

\section{Řízení krizí}

Operační centrum dohledu a podpory řízení vnějších krizí; Meziministerské centrum řízení krizí; Evropské centrum pro civilní ochranu; Národní centrum pro telefonické povolávání.

\section{Ministerstvo obrany}

Vševojskové velitelství pro kosmický prostor; Ministerská komise pro obranné investice; Finanční výbor ministerstva obrany.

\section{Ministerstvo vnitra}

Ústřední ředitelství vnitřního zpravodajství; Ředitelství pro výhled a strategii; Ředitelství pro plánování; Výbor prefektů zón obrany a bezpečnosti; Evropské centrum vyšetřování a koordinace boje proti drogám v oblasti Středozemního moře; Specializovaná služba boje proti financování zakázaných aktivit; Ekonomická a vědecká rada bezpečnosti.

Dále je předpoklad vytvoření celé řady orgánů v oblasti vzdělávání, výzkumu bezpečnosti, ale i na výkonné úrovni.

\section{ZÁVĚR}

Bílá kniha obrany a bezpečnosti Francie velmi zásadně mění celkový přístup země k této problematice vyvolaný objektivní nutností změn, zejména pod tlakem vývoje mezinárodního bezpečnostního prostředí. Z obsahu Bílé knihy lze také vysledovat podstatně komplexnější př́ístup $\mathrm{k}$ bezpečnosti země, což nadále již nemá být jen problematikou obrany, ale ve své podstatě se bude dotýkat celé státní správy a samosprávy i občanů samotných. Občan se do budoucna stane ústř̌edním prvkem strategie obrany a bezpečnosti a bude také sehrávat rozhodující roli ve společném úsilí pro naplnění cílů obrany a bezpečnosti.

Přestože Bílá kniha je přijímána rozporuplně, a to i ve Francii samotné, lze vyslovit názor, že se stává, alespoň v evropském měřítku, novým impulsem pro úvahy o bezpečnosti a obraně ve věku globalizace. Přes všechny možné výhrady se Francie se svojí Bílou knihou může stát vzorem pro uzpůsobení národních strategií bezpečnosti a obrany v dalších zemích. Pouze budoucí vývoj ukáže dobré i negativní stránky dokumentu samotného i jeho realizace.

\section{LITERATURA}

[1] Livre blanc sur la défense et la sécurité [online]. Ministère de la défense, 2008 [cit. 2008-0930]. 350 s. Dostupný z WWW: 〈http://www.defense.gouv.fr/livre_blanc>. 